\title{
Aromatic and Steroid Compounds from Smilax Bracteata C. Presl. (Smilacaceae), a Bornean Medicinal Herb
}

\author{
Julius Kulip*, Takashi Kamada and Charles SV
}

Institute for Tropical Biology and Conservation, Universiti Malaysia Sabah, Jalan UMS, 88400 Kota Kinabalu, Sabah, Malaysia

\begin{abstract}
The medicinal herbs, Smilax bracteata C. Presl. (Smilacaceae) or commonly known as Tongkung in North Borneo Island was used traditionally for treatment of ailments in various Dusun villages in Sabah, Malaysia. One aromatic compound seselin (1) and two steroids $\beta$-sitosterol (2) as well as stigmasti-4-ene-3-one (3) were isolated and identified as major secondary metabolites from this plant. Their chemical structures were elucidated using $1 \mathrm{H}$, 13C and 2D NMR. These chemical compounds have shown to possess variety of biological activities such as anticancer, anti-fungal and anti-inflammatory. Therefore, the ailments of local native Dusun people in Sabah, Malaysia were treated due to the presence of these compounds in S. bracteata.
\end{abstract}

Keywords: Phytochemical; Seselin; $\beta$-sitosterol; Stigmasti-4-ene-3one; Smilax bracteata C. Presl

\section{Introduction}

The medicinal herb, Smilax bracteata C. Presl. is a monocotyledon species in the family of Smilacaceae. There are about 261 species and 240 infraspecific species (IPNI, 2015) which are distributed in tropical and subtropical regions, with some herbaceous species extending their range into the temperate regions of North America, Europe and Asia. The greatest diversity is found in eastern Asia. In Indo-China 27 species have been found, in Thailand 24 species, and the number of species is probably slightly less in Malaysia [1]. In Sabah, S. bracteata grows commonly at forest fringes from sea level up to $900 \mathrm{~m}$ above sea level. This plant is listed one of the 1,300 medicinal herbs in Sabah [2]. This plant was known as Tongkung by Dusun people in Sabah and it was a common practice for local people to reduce blood pressure using this herb [3]. According to [4] this plant was used to cure depurative, dysmenorrhea, rheumatism, skin and syphilis in East Malaysia. However, only a few studies on their chemical compositions were conducted. Previously, this genus Smilax was known to contain saponin and phenolic compounds as their major metabolites [5]. Therefore, we report the phytochemical analysis of $S$. bracteata and this is the first record for Malaysia's specimen.

\section{Methodology}

\section{Collection}

An ethnobotanical literature surveys was conducted in early January 2015 to search the most suitable traditional medicinal herbs/ plants and S. bracteata was chosen the best candidate for this research. The leaves samples were collected from Tudan Village in Tuaran District, Sabah, North Borneo Island in $19^{\text {th }}$ January 2015 and the scientific name of this plant was identified by the first author. Tudan Village was located at the boarder of Tambunan District and about 60 $\mathrm{km}$ from Kota Kinabalu by road to the east. It was about $1,300 \mathrm{~m}$ above sea level. The population here was Dusun Kimaragang sub-tribe. The samples were collected, photographed and a made Voucher Specimen (BORH 2456) and it was kept at the BORH Herbarium of the Institute for Tropical Biology and Conservation, Universiti Malaysia Sabah (Figure 1). The samples were weighed and processed according to the procedures described [6].

\section{General experimental procedures}

Optical rotations were measured on an AUTOPOL IV automatic polarimeter (Rudolph Research Analytical, Hackettstown, NJ,
USA). IR spectra were obtained on a Thermo Nicolet Avatar FTIR spectrophotometer (Thermo, Tokyo, Japan). The NMR spectral data were recorded on JEOL ECA 600 instrument $\left(600 \mathrm{MHz}\right.$ for ${ }^{1} \mathrm{H}$ and $150 \mathrm{MHz}$ for ${ }^{13} \mathrm{C}$; JEOL, Tokyo, Japan) with tetramethylsilane (TMS) as an internal standard. The HR-ESI-TOFMS data were obtained on a LCMS-IT-TOF (Shimadzu, Kyoto, Japan). Preparative TLC was performed with silica gel plate (Merck, Frankfurt, Germany; Kieselgel $\left.60 \mathrm{~F}_{254}\right)$. Column chromatography $(\mathrm{CC})$ was performed on silica gel (70-230 mesh; Merck, Frankfurt, Germany). Analytical TLC was performed on Merck Kieselgel $60 \mathrm{~F}_{254}$. Spots were visualized by UV light or by spraying with a $5 \%$ phosphomolybdic acid-ethanol solution.

\section{Extraction and isolation}

Dried leaves of $S$. bracteata $(500 \mathrm{~g})$ were extracted with methanol $(\mathrm{MeOH})$ at room temperature for 5 days. The resulting $\mathrm{MeOH}$ extract was concentrated in vacuo and the concentrate was partitioned between ethyl acetate (EtOAc) and distilled water. The EtOAc extract (1.0 g) was then fractionated using silica gel column chromatography with a step gradient of hexane (Hex) and EtOAc with the ratio 9:1, 8:2, 7:3, 5:5 and $100 \%$ EtOAc. The third fraction was then further isolated using preparative thin layer chromatography (PTLC) $100 \%$ chloroform to obtain $\mathbf{1}(28.3 \mathrm{mg})$ and $\mathbf{2}(80.0 \mathrm{mg})$. Fourth fraction was further isolated using PTLC Hex and EtOAc with the ratio 2:1 to obtain 3 (64.0 mg).

\section{Results and Discussion}

The partially dried specimens of $S$. bracteata collected at Tudan Village in Tuaran District, Sabah, North Borneo Island, were extracted with methanol. A combination of column and thin-layer chromatographies of the methanol extract yielded 1 ( $28.3 \mathrm{mg} ; 2.8 \%)$, $2(80.0 \mathrm{mg} ; 8.0 \%)$ and $3(64.0 \mathrm{mg} ; 6.4 \%)$. Yields were calculated as percentage of EtOAc crude extract. From above findings, these three compounds were major compounds from this crude extracts. The

*Corresponding author: Julius Kulip, Institute for Tropical Biology and Conservation, Universiti Malaysia Sabah, Jalan UMS, 88400 Kota Kinabalu, Sabah, Malaysia, Tel: 60 88-320 000; E-mail: julkulip@yahoo.com

Received July 13, 2015; Accepted August 01, 2015; Published August 03, 2015

Citation Kulip J, Kamada T, Charles SV (2015) Aromatic and Steroid Compounds from Smilax Bracteata C. Presl. (Smilacaceae), a Bornean Medicinal Herb. Nat Prod Chem Res 3: 184. doi:10.4172/2329-6836.1000184

Copyright: @ 2015 Kulip J, et al. This is an open-access article distributed under the terms of the Creative Commons Attribution License, which permits unrestricted use, distribution, and reproduction in any medium, provided the original author and source are credited. 
Citation: Kulip J, Kamada T, Charles SV (2015) Aromatic and Steroid Compounds from Smilax Bracteata C. Presl. (Smilacaceae), a Bornean Medicinal Herb. Nat Prod Chem Res 3: 184. doi:10.4172/2329-6836.1000184

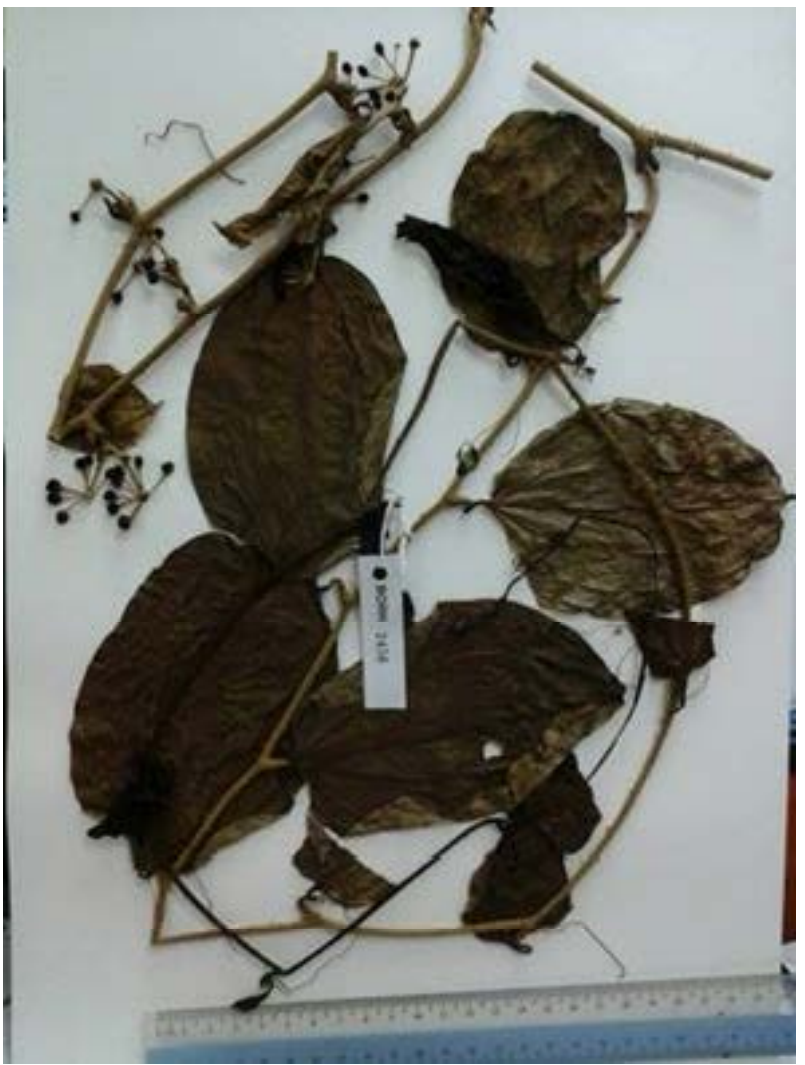

Figure 1: Voucher specimen of Smilax bracteata C. Prest. (BORH No. 2456).

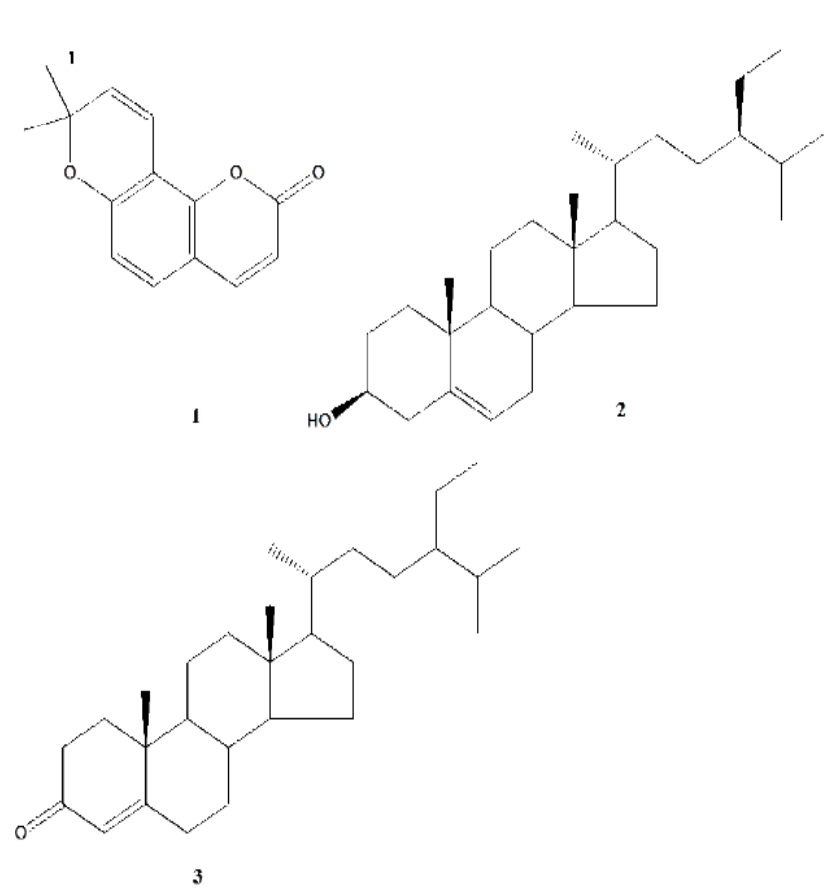

Figure 2: Structure of isolated compounds 1-3 from Smilax bracteata C. Presl 1. Structure of Seselin

2. Structure of $\beta$-sitosterol

3. Structure of Stigmast-4-ene-3-one known compounds 1-3 (Figure 2) were elucidated based on comparison of previous data [7-9].

In the past, seselin (1) was isolated from various terrestrial plants, Clausena anisata and Sesamum indicum, and showed strong bioactivity such as anti-inflammation, anti-fungal and pyrethrins detection $[7,10]$ Meanwhile, $\beta$-sitosterol (2) and stigmast-4-ene-3-one (3) were common sterol in terrestrial plants and especially 2 was reported many bioactivities such as anti-inflammation, anti-oxidant and anti-cancer [11].

In conclusion, this was first record about phytochemical analysis of Malaysian S. bracteata and three major compounds seselin (1), $\beta$-sitosterol (2) and stigmast-4-ene-3-one (3) were isolated. These secondary metabolites were reported to show various biological activities. Therefore, the results of chemical component analysis for $S$. bracteata suggested the importance about local medicinal herbs in Sabah.

\section{Acknowledgement}

This study was supported by SPGUMS Grant No. SLB005-SG-2012. The authors would also like to acknowledge Mr. James P. Kulip from Timbou Village, Tambunan District and Mr. Johnween Galuk from Tudan Village, Tuaran District for their kind assistances during field survey.

\section{References}

1. Teo SP (1999) Smilax L. PROSEA (Plant Resources of South-East Asia) Foundation, Bogor, Indonesia de Padua LS, Bunyapraphatsara N and Lemmens RHMJ (Eds).

2. Kulip, J. (2004). Medicinal plants in Sabah: How much do we know? Paper presented at the Seminar 2004 on Medicinal Plants and the Herbal industry: Opportunities and Challenges. Jointly organised by FRIM,UMS and BHCS.

3. Kulip J (1996) A survey of indigenous plants used for food and medicine by the Kadazan/Dusun ethnic in Tambunan, Sabah, east Malaysia University, Brunei, Darussalam.

4. Burkill HR (1966) Dictionary of the Economic Products of Peninsular Malaysia. Singapore Gardens Bulletin Vol I and II.

5. Li SY, Fuchino H, Kawahara N, Sekita S, Satake M (2002) New Phenolic Constituents from Smilax bracteata. J Nat Prod 65: 262-266.

6. Kamada T, Vairappan CS (2012) A new bromoallene-producing chemical type of the red alga Laurencia nangii Masuda. Molecules 17: 2119-2125.

7. Mukandiwa L, Ahmad A, Eloff JN, Naidoo V (2013) Isolation of seselin from Clausena anisata (Rutaceae) leaves and its effects on the feeding and development of Lucilia cuprina larvae may explain its use in ethnoveterinary medicine. J Ethnopharmacol 150: 886-891.

8. Chaturvedula VSP, Prakash I (2012) Isolation of Stigmasterol and $\beta$-Sitostero from the dichloromethane extract of Rubus suavissimus. International Current Pharmaceutical Journal 1: 239-242.

9. Kolak U, Topçu G, Birteksöz S, Ötük G, Ulubelen A (2005) Terpenoids and Steroids from the Roots of Salvia blepharochlaena Laurencia nangii blepharochlaena. Turkish Journal of Chemistry 29: 177-186.

10. Norma CCO, Cuauhtemoc PG, Miguel AZS, Abhril BHR, Salud PG (2007) Antifungal activity of seselin in protecting stored maize from Aspergillus flavus. Asian Journal of Plant Sciences 6: 712-714.

11. Saeidnia S, Manayi A, Gohari AR, Abdollahi M (2014) The story of $\beta$-sitosterol European Journal of Medicinal Plants 4: 590-609. 